\title{
Russian Middle Class: Special Aspects of Structure and Financial Behavior
}

\author{
Svetlana Anatolievna Ilinykh* \\ Novosibirsk State University of Economics and Management, Russian Federation; ili.sa@mail.ru
}

\begin{abstract}
Background/Objectives: This study aims to examining the urban middle class, namely the specifics of its professional portrait, self-identification and peculiarities of economic behavior.

Methods/Statistical Analysis: The methodological basis of the study includes the fundamental ideas of theoretical sociology, comparative analysis, and interdisciplinary approach. The study is based on the conceptual works and the research results of Russian and foreign authors devoted to the analysis of class and gender aspects of social transformations in the countries of Western Europe, America and Russia. Questionnaire surveying of 276 men and 395 women was used as an empirical method. The representativeness of the sampling is provided by maintaining the age and sex structure of the adult population, the proportions between the population size in different districts of the city (sampling error does not exceed 3\%). Findings: On the basis of the developed methodology of the study it is revealed that representatives of the urban middle class differ in their attitude to work as compared to other classes. When studying this question it is required to consider instrumental and spiritual aspects. Economic behavior of the middle class is more variable. This is particularly evident in the situation of the need to improve their financial well-being. The middle class is characterized by a considerable rational financial behavior. The essential feature of the urban middle class is the availability of modern investment mentality, what is new in the study of the representatives of the social strata under investigation. Because of their social status, the middle class is interested in social stability, universal respect for the law, therefore, in improvement of the efficiency of the state bodies' work and elimination of various barriers preventing effective business. This confirms the idea that the middle class is the main productive force of society, contributing to the stability of the latter. The investigation of gender aspects should be considered as a novelty of the study. Applications/Improvements: The obtained results allow complementing the notions of self-identification, the middle-class structure, and its economic behavior. These findings can be used in further research on gender issues.
\end{abstract}

Keywords: Class, Economic Behavior, Gender, Self-Identification, The Middle Class Structure

\section{Introduction}

Over recent decades the condition of Russian society has been in the focus of attention of the country's and international researchers. At the same time, while in the first half of the 90s the trends taking place in Russia were described mainly in terms of "a transition from totalitarianism to democracy", at present moment most analysts conclude that it would be wrong to consider Russia as a society turning into a Western-style democracy ${ }^{1}$.
The last two decades of Russian history can be described as the period of social transformations which influenced all levels of the public command hierarchy (national, regional, local, macro- and microsocial ones), as well as they cause a fundamental change of institutions and social practices: the institutional and class structure of the society, its ideology, gender relations, and family ${ }^{2}$. This approach is considered in the works of Russian and international scientists working in the field of social philosophy, history, sociology, political science

${ }^{*}$ Author for correspondence 
and economics. An important feature of transformation processes in Russia is that they can hardly be controlled by the political elite. This determines the need for social sciences to assess and analyze the consequences of these transformations regarding changes in activity, values and life strategies of different social actors, as well as the spread of new social practices.

The relevance of the study stems from the need for, first, empirical research on the middle class both in Russia and in Novosibirsk through working out the sociological profile of the middle class at the present stage of the society development, and, secondly, the study of gender practices of the middle class representatives who initiate and trigger the transformation of social institutions, their behavior reinforcing and affecting the outcomes of these transformations.

The specific feature of the modern stage of the society development is the fact that in Russia it is still not clear who can be identified as a middle class representative. At the same time, determining what groups the middle class can be divided in seems to be an important issue, as well as the conditions under which this or that group of the middle-class expands or contracts. Thus, the characteristic feature of the middle class in Russia today is not actually a much lower level of living if compared to Western countries, but a sufficiently large "periphery" of the middle class, some of which, under certain conditions, can quickly become part of it. In this regard, it should be mentioned that every second representative of the middle class periphery cannot join this social group only because of low income. In addition to this, more than half of this group is the employees of publicly funded institutions (education, science, health care), and their circumstances can rapidly change in case of, for example, salary increase or successful implementation of national projects, so this would allow considering this group as a significant source for the replenishment of the middle class.

Another relevant issue is the characteristic of a typical representative of the middle-class urban population, of the "old" and "new" middle class. The specific features of the middle class self-identification and, as a result, gender practices of the middle class are another pressing matter. Thus, sociological research on the middle class in Russia will provide a more or less complete description of the middle class as complex phenomenon, possessing its own internal structure and differences in the origin of certain social layers, being part of this structure, as well as differences in gender practices.
The relevance of the study also stems from the fact that research on the middle class, as a rule, is carried out in the large cities of Central Russia - Moscow, St. Petersburg ${ }^{3,4}$, and others. The first attempt to assess the Russian middle class was made immediately after the 1998 financial crisis. The crucial question was whether the still fragile middle class of the new Russia had survived in the crisis. The fact that it did, though had shrunk in size, was proven by a national sociological survey conducted in the spring of $1999^{5}$.

The second attempt to analyze the middle class was made in the summer of 2003, during a nationwide survey which included both representative sample of Russian population and a special sub-sample of most prosperous social groups of the Russian society, which enabled to increase the representativeness of the sample. Researchers were primarily interested in the state of the middle class in the new political conditions, dynamic pattern of its qualitative and quantitative characteristics in the postcrisis period.

A new study of the Russian middle class was held in February, 2014, its main purpose being the assessment of its size, composition, characteristics, social role in development prospects. The total volume of study sample amounted for 1,900 people ${ }^{5}$.

In Novosibirsk, a similar study was conducted in 2010 as part of the research on the potential of the population in the Novosibirsk region in the context of modernization. Here we should mention that the middle class in the city of Novosibirsk itself was not studied properly since only some minor aspects of this phenomenon were considered.

To obtain a broader perspective revealing the scientificeducational, intellectual, economic, innovative and other potential of the middle class, it was necessary to conduct a comprehensive empirical study. The research done previously paid almost no attention to the aspect of gender.

Thus, the scientific challenge arises from the fact that many issues have not been properly investigated, these issues concerning, on the one hand, the modern sociological profile of the middle class in Russia and in Novosibirsk. On the other hand, the issues of gender practices, gender roles, gender culture of the middle class have also been understudied.

It is the middle class representatives who mainly face the problem of finding a perfect balance between "work and life", the optimum compromise between work routine and self-realization. What's more, it is the middle class 
representatives who mention a greater importance of the quality of life including both its subjective (satisfaction, happiness) and objective characteristics (health, career, privacy, etc.). These issues are influenced by a range of gender practices, stereotypes, etc., which all together determine the social problem of the research project.

\section{Literature Review}

The fundamental ideas and principles of theoretical sociology, comparative analysis and interdisciplinary approach form the methodological basis of the study. The research is based on leading works and research results of Russian and international scientists devoted to the analysis of class and gender aspects of social transformations in the countries of Western Europe, the USA and Russia.

The review of scientific works of Russian and international scientists devoted to the analysis of theoretical and methodological issues of the research on the middle class provided us with the information concerning the previously published works. The research on the middle class can be traced back to the antiquity and was first undertaken by Aristotle and Euripides. A significant contribution to the study of social stratification was made by such researchers as M. Allen ${ }^{6}$, E.D. Baltzell', D. Brooks ${ }^{8}$, R. Miliband ${ }^{9}$, D.U. Domhoff ${ }^{10}, H$. Zeidler ${ }^{11}$ and other sociologists.

Various issues concerning the middle class and its role in the economic life of the country have also been discussed in the papers by such scholars as Max Weber ${ }^{12}$, Ralf Dahrendorf ${ }^{13}$ and others. As for Russian researchers investigating the issues of the middle class, we should mention T. M. Maleva and L. N. Ovcharova ${ }^{4}, Z$. Golenkova ${ }^{14}$, M. K. Gorshkov ${ }^{5,15}$, N. V. Dychko ${ }^{16}$, T. I. Zaslavskaya ${ }^{2,17}$, A. N. Tarasov ${ }^{18}$, N. E. Tikhonova ${ }^{3,19}$, O. I. Shkaratan, S. A. Inyasevsky, T. S. Lyubimova ${ }^{20}$ and other scholars. The class structure is considered in the works $\mathrm{s}^{21,22}$ and others.

The gender issues are studied in the work ${ }^{23-27}$ and others.

Considering the theoretical aspect of the problem, it is very important to determine the criteria which are applied to identify and define the middle class in contemporary Russian society. In this regard, it should be mentioned that there are four basic approaches among the ones most frequently used in modern sociology to identify the middle-class. The first one deals with the common conception of the middle class as the mass social subject characterized by a relatively high standard of living and consumption level. According to the second approach, to determine the criteria of the middle class one should focus not on the material, but on self-identification and psychological characteristics of an individual. The third approach states that the middle class can be divided into the so-called "new" middle class, including managers and professionals, and the "old" middle class - the socalled "small business", which receives dividends on its economic capital. The fourth approach represents an attempt to use the set of traditional criteria which would ensure a comprehensive identification of the middle class in Russia: certain professional characteristics, education, self-identification, property and income characteristics.

Scientific papers often use the level of material wellbeing as the main and sometimes the only criterion for identifying the middle class. It is absolutely clear why this criterion is so commonly used. For example, in their study American scientists ${ }^{28}$ aimed at determining the size and describing the middle class in various countries use indicators referring to the household incomes. Proving their decision, the researchers state that this criterion enables to conduct cross-country studies, as well as to register the changes in the size of the middle class, occurring over time. The central idea of the approach implies placing the middle class in the middle of the median, rather than choosing a certain level of life or a specific type of behavior.

B. Barber ${ }^{1}$ proposes the following criteria of stratification: 1) occupational prestige; 2) the volume of authority and power; 3) income or wealth, 4) education or knowledge; 5) religious or ritual purity; 6) belonging to a family and 7), belonging to a certain ethnic group. P. Blau ${ }^{29}$ mentions the following stratification criteria: education, income, wealth, prestige, power, origin, age, administrative position.

Stratification criteria can be compiled and reduced to the following types: economic ones - private property, annual income, material well-being; political criteria - the amount of personal power, position, fame; educational criteria - a type of education, academic degree and title; professional ones - position, professional skills and qualifications.

The most developed classification belongs to W.L. Warner ${ }^{22}$ and it defines six main classes: 1) the upper upper class. This is represented by individuals with the highest level of financial security, the aristocrats; 2) the lower upper class. This includes individuals who do not belong to aristocracy, but have the level of income no lower than the top representatives of the upper class; 3 ) the 
upper-middle class - the intellectual elite of the society, the bourgeoisie; 4) the lower middle class - professionals doing non-physical work; 5) the upper lower class - the category of the population engaged in mass production, mainly in the field which requires certain physical labor; 6) the lower lower class - individuals without education, employment, with temporary employment at low-paying jobs or living on the welfare ${ }^{22}$. Later, William Watson ${ }^{30}$ added a new stratum to this classification - the "middle" middle class which is the basis of the civil society. Mainly, these are highly qualified business professionals, managers, entrepreneurs, lawyers, teachers, and so on. A significant expansion of the "new" middle class due to a large number of managers, who do not own any property and do not run businesses, was called "the managerial revolution".

\section{Materials and Methods}

The methodological basis of the study was formed by the fundamental ideas and principles of theoretical sociology, comparative analysis, and interdisciplinary approach. The study is based on the leading works and research results of Russian and international scholars devoted to the analysis of class and gender aspects of social transformations in the countries of Western Europe, the USA and Russia.

The research on the middle-class studied 276 men and 395 women living in the city of Novosibirsk. Most of the respondents have permanent employment (men $-52.5 \%$, women $-60.3 \%$ ). Among men, $22.1 \%$ run their own business, for women this figure was $5.8 \%$. Small business was the most common business type, with a number of employees in most cases under 10 people (men - 26.7\%, women $-7.3 \%$ ). For $13.3 \%$ of men and $7.9 \%$ of women the number of staff varied from 10 to 30 people.

The sample may be considered representative since it correlates with the sex-age structure of the adult population, the ratio of the population sizes in different areas of the city (with sampling error of no more than 3\%). The calculations are based on incremental subsampling of the variables of the criteria used.

\section{Findings}

\subsection{Occupational Profile of the Middle Class}

Occupational profile of the Novosibirsk middle class reflects the characteristics of the current historical period of Russia's development and economic model, which have emerged over the reform years. The current stage of the development of Russian economy may be described as the late industrial development, which the Western countries passed in the 1960-80s.

Therefore, the occupational profile of the Novosibirsk middle class significantly resembles the middle class of the developed countries in the earlier days. For example, in Russia, its size and growth are generated mainly by the increase of "white-collar jobs" with relatively high salaries in banks, financial sphere, trade, service sector, housing and utility sector. This means that the share of semi-skilled employees in the composition of the middle class has grown.

The conclusion made by the Institute of Sociology in the 2015 study appears to fully correlate with the Novosibirsk middle class. The conclusion M.K. Gorshkov $^{5}$ arrived at stated that the fundamental expansion of the middle class can only occur in the situation of the country's economic development diversification, the transition to the "knowledge economy", innovation in industrial production and the development of the quaternary sector.

As for the attitude to work, the middle class representatives perceive it not only as a source of livelihood, but also as a means of self-realization (see Figure 1).

Achieving goals, rational approach turned out to be the most relevant aspects to the middle class representatives. It is significant that people belonging to the middle class value their qualifications and job and are successful in this field, which allows them to feel confident and to identify themselves with people of the same social standing.

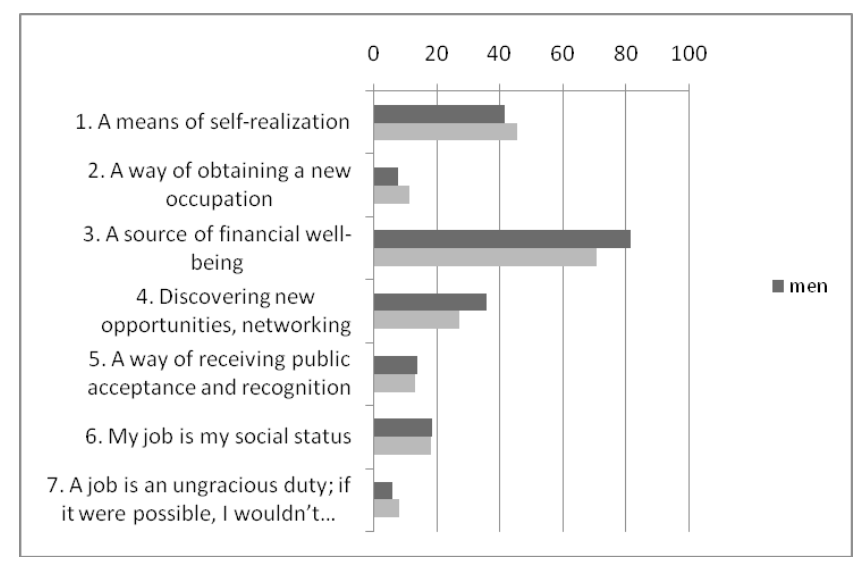

Figure 1. Distribution of the answers to the question "Please, indicate how important your job is to you (choosing no more than 3 options)", (\%). 


\subsection{Specific Features of the Urban Middle Class Self-Identification}

To formulate the criteria of the middle class self-identification, it is necessary to determine the levels of the middle class. Most accurately, the task of the middle class identification was accomplished in the works ${ }^{4}$ L. Grigoriev, A. Salmin, O. Kuzina ${ }^{31}$ consider the upper middle, middle, lower middle and the proto lower middle class. To identify the middle-class of Novosibirsk we can apply the stratification of the middle class, presented in the works of the leading Western scientists. For example, A. Giddens ${ }^{21}$ names three main classes typical of the Western societies. The upper class owns or directly controls the production resources. This group of people includes the rich, the big industrialists, top management. Most "white-collar" and professionals belong to the middle class.

To identity the Novosibirsk middle class, it is possible to apply the classification by W.L. Warner ${ }^{22}$. According to the results of the study, the structure of the Novosibirsk middle class is heterogeneous. The survey revealed that $21.4 \%$ of men and $8 \%$ of women identify themselves with the upper middle class. About $40 \%$ of men and $60 \%$ of women named themselves as the middle middle class. $24.3 \%$ of men and $22.8 \%$ of women see themselves as representatives of the lower middle class.

Even though, from our perspective, the set criteria ensured that the survey would involve the middle class only, $7.2 \%$ of men and $1.8 \%$ of women stated they belonged to the upper class. Indeed, it was found that their level of monthly income per person is very high, they have several real estate objects, including those abroad, several cars in the family, can afford an expensive holiday several times a year, etc. It is worth noting that this issue requires further study.

Thus, the conducted survey allows us to conclude that the share of the middle middle class in Novosibirsk varies from 40 to $60 \%$, which is consistent with the results of the sociological research by M. Gorshkov in $2015^{5}$.

\subsection{Specific Features of the Middle Class Financial Behavior}

To answer the question to what extent the emerging middle class in Novosibirsk could become the basis for both an economically prosperous city and the country, it is necessary to consider not only its human capital, but also real behavioral practices of the middle class, as well as specific features of its financial tactics. In this regard, it is also important to determine which of these practices, values and attitudes are "stimulated" by the society through the system of material and career incentives, and how common they are in the middle class.

According to the survey results, $22.1 \%$ of men and $5.8 \%$ women run their business. In most cases it is small business. Considering the gender aspects, we can conclude that men are four times more likely to run a business than women.

Besides, women are four times less likely to take a position in top management and almost six times less likely to become heads of large departments. At the same time, the number of women working as leading experts and officials even exceeds that of men. These data confirm the general gender trends identified by researchers in labor market.

The study identified the measures the representatives of the Novosibirsk middle class take to improve their material well-being. According to the data, men are more proactive. We can assume that women experience a heavier "burden" of household responsibilities, which does not allow them to fully resort to various ways of increasing their financial well-being.

In this regard, we should highlight that the middle class, unlike the rest of the urban population, in general is more careful to its property. For example, talking about the real estate, the middle class representatives are not only more accurate with paying related taxes, but are also much more likely to invest in the repair and maintenance of their property.

A great popularity of such strategies as making savings (the middle class willingly adopts this strategy) and borrowing (the middle class does it reluctantly, but if there is such a need, these are loans for purchasing expensive durable goods, real estate) raises questions how rational the financial behavior of its representatives is, as well as how we can define their financial behavioral strategies, the ways of available funds distribution.

The study of the Novosibirsk middle-class provides a characteristic gender analysis of the available funds distribution. We can trace gender aspects regarding the investment of available funds in business, property, money saving, paying for medical treatment and education, investment in securities and furniture purchase. Men often prefer active and risky ways of money investment, whereas women stick to a totally different strategy.

The Novosibirsk middle class often uses available funds for the purchase of durable goods, renovation of 
the property. These behavioral practices can be called traditional. Along with this, there is a qualitatively different strategy - active investment in commercial banks to obtain the beneficial interest and investment in real estate (for men), as well as less common ones - investment in their business (for men). Women are more likely to invest in human capital (both their own and their children). All these strategies make it possible to conclude that the middle class can be seen as the carrier of the modern investment mentality.

\section{Discussion}

The data obtained in the course of study allow us to make the following conclusions:

1. The middle class, unlike other classes, has a special attitude to work. It is seen not only as a tool, as a source of livelihood, but also from a spiritual perspective as a means of self-realization. At the same time, achieving results, rationality of actions are believed to be the crucial aspects of career. This confirms the idea that the middle class is the main productive force of the society, contributing its stability.

2. The structure of the middle class is heterogeneous. It is made up of the representatives of three layers: the upper, middle, and lower middle class. $40 \%$ of man and $60 \%$ of women define themselves as the middle middle class. However, the conducted study reveals the need for further development of Warner's classification since the middle class is actually made up of a higher number of layers. Therefore, developing a clear set of criteria for such classification appears to be a highly relevant issue.

3. The financial behavior of the middle class is different from that of other classes as it is more variable when it comes to improving their financial well-being. The middle class uses highly rational financial strategies. In addition to that, the modern investment mentality is a specific feature of the middle class. Due to their social status, the middle class is interested in social stability, universal respect for the law and, therefore, in improving the efficiency of the government bodies as well as eliminating various barriers hindering effective business.

4. The middle class, like other social groups, has some specific ways of gender aspects manifestation, which influences occupations distribution and financial behavior.

\section{Conclusion}

Thus, the ability of the middle class to act as the main productive force of the society, its contribution to the society's stability may be named among its strong points. In contrast to the "higher", the middle class does not have the instruments for deriving personal profit from public institutions and public finances. Unlike the "lower" class, the middle class does not need large social transfers from the state budget for the maintenance of a minimally acceptable standard of living.

The leading factors in the job motivation for this social group relate to the content of their work, perceived by them not just as a source of livelihood, but also a means of self-realization. At the same time, the further growth of the middle class directly depends on the certain trend of the labor market development, its demand for highly skilled professionals. The middle class is characterized by adopting a wide range of financial behavior strategies as well as the modern investment mentality. However, the middle class also demonstrates certain gender practices that influence the job structure and its financial behavior.

The structure of the middle class is much more diverse than the current classification which considers three layers only - the higher, middle and lower. All this requires the development of criteria for further comprehensive theoretical and empirical research on the classification of the middle class.

\section{Acknowledgements}

This study (Number of project 03/2015) was supported by the grant of the Novosibirsk State University of Economics and Management in 2015.

\section{References}

1. Barber B. The Structure of Social Stratification and the Trends of Social Mobility. American Sociology: Prospects, Problems and methods. Moscow: Progress, 1972.

2. Zaslavskaya TI, Gromova RK. On the "Middle Class" in Russian Society. Mir Rossii. 1998; 4:18-25.

3. Tikhonova NE, Gorshkov MK. Criteria of distinguishing and determining the middle class number in the modern Russian society. In Middle Class in Contemporary Russia. Analytical report. Moscow: Institute of Sociology RAS. 2008; 12-24. 
4. Maleva TM, Ovcharova LN. Russian Middle Classes on the Eve and at the Peak of the Economic Crisis. Moscow: Econom-Inform, 2008; 7-102.

5. Gorshkov MK. Middle Class as the Reflection of the Economic and Socio-cultural Models of the Russia's Current Development Model. Sociological Studies. 2015; 31:35-44.

6. Allen R. Elite Social Movement Organizations and the State. Moore G. Research in Politics and Society. New York: JAI Press, 1993.

7. Baltzell ED. Philadelphia Gentlemen: The Making of a National Upper Class. Whitefish Literary Licensing LLC, 2011.

8. Brooks D. Bobos in Paradise: The New Upper Class and How They Got There. Thorndike Press, 2001.

9. Miliband R. The State in Capitalist Society. An Analysis of the Western System of Power. London, 1993.

10. Domhoff GW. Who Rules America: The Triumph of the Corporate Rich. New York: McGraff-Hill, 2014.

11. Zeidler H, Schubert L. The Irony of Democracy: in Uncommon Introduction to American Politics. Boston: Cengage Learning, 2011.

12. Weber M. Selected Works. Moscow: Progress, 1990.

13. Dahrendorf R. Certain Aspects of the Social Conflict Theory. Sociological Studies. 1994; 5:142-6.

14. Golenkova ZT. Social Stratification of Russian Society. Moscow: Let.sad., 2003.

15. Gorshkov MK, Tikhonova NE. The Middle Class as the Social Base for Russia's Competitiveness. Russia Reformed. Yearbook. Moscow: Institute of Sociology, RAS, 2005.

16. Dychko NV. Development of the Mechanisms of the Middle Class Formation in the Context of Transformation Economy. Public Administration and Civil Service. 2008; 4:75-83.

17. Zaslavskaya TI. Modern Russian Society: Problems and Prospects. Social Sciences and Today's World. 2004; 5:5-15.

18. Tarasov AN. Economic interests of the middle class: monograph. Saratov: Saratov State University Press, 2003.
19. Tikhonova NE. Specific Features of the Status Identity and the Middle Class Consumption. Sociological Studies. 2015; 31:44-55.

20. Shkaratan OI, Inyasevsky SA, Lyubimova TS. The New Middle Class and Knowledge Workers on the Russian Labor Market. Social Sciences and Today's World. 2008; $1: 5-27$.

21. Giddens A. Stratification and Class Structure. Sociological Studies. 1992; 9.

22. Warner WL. Social Class and Social Structure. Rubezh. 1997; 10-11:42-57.

23. Zdravomyslova OM. Gender Aspects of Modern Russian Transformations: Research Methodology Issues. Thesis. Doctor of Philosophy. Moscow, 2008.

24. Zdravomyslova EA, Temkina AA. Creation of Gender Identity: Methodology for the Interview Analysis. Gender Studies. 2000; 5:211-25.

25. Ilinykh SA. Identification of Gender Culture Aspects: Case Study of Gender Stereotypes. Bulletin of the Buryat State University. 2010; 14:119-23.

26. Ilinykh SA. Gender as the Subject of Management of Men and Women. Current Research. Monograph. LAP LAMBERT Academic Publishing GmbH \& Co. KG, 2011.

27. Ilinykh SA. Gender Theory of Management. Ideas and Ideals. 2012; 1(2):115-26.

28. Birdsall N, Graham C, Pettinato S. Stuck in the Tunnel: Is Globalization Muddling the Middle Class? Carnegie Endowment for International Peace. Discussion Paper No 1. 2000 Nov.

29. Blau P. Inequality and Heterogeneity: A Primitive Theory of Social Structure. New York: Free Press., 1977.

30. Watson W. The Inequality Trap: Fighting Capitalism Instead of Poverty. Toronto: University of Toronto Press, 2015.

31. Grigoriev L, Salmina A, Kuzina O. Russian Middle Class: Analysis of its Structure and Financial Behavior. - Moscow: Ekon-Inform, 2009. 